\title{
VESICAL EXPLOSION DURING TRANSURETHRAL RESECTION OF THE PROSTATE: REPORT OF A CASE.
}

\author{
Matheus Neves Ribeiro da Silva, Antonio Correa Lopes Neto, João Paulo Zambon, Maurício \\ Jacomini Verotti y Eric Roger Wroclawski.
}

From the Department of Urology of the ABC Medical School. Santo André. Sao Paulo. Brazil.

\begin{abstract}
Summary.- OBJECTIVE: Vesical perforation during transurethral resection of the prostate (TURP) is usually related to high increases in intravesical pressure. However, it may rarely be related to explosion precipitated by the contact of the electrocautery with some gases produced during the resections. The authors present a case of vesical explosion, discuss its mechanism and suggest some measures for prevention.
\end{abstract}

METHODS/RESULTS: A 71-years-old male underwent TURP and hemostasy of bleeding from the bladder neck due to persistent hematuria. A wire loop electrode set at a cutting and coagulating current of 80 watts was used. During coagulation of a bleeding in the anterior aspect of the vesical neck when the bladder was empty, a loud pop was heard and a jolt was felt at the lower abdomen. Inspection revealed a hole in the dome of the bladder with loops of small bowel visible. A low midline incision was done, and the intraperitoneal bladder rupture was repaired.

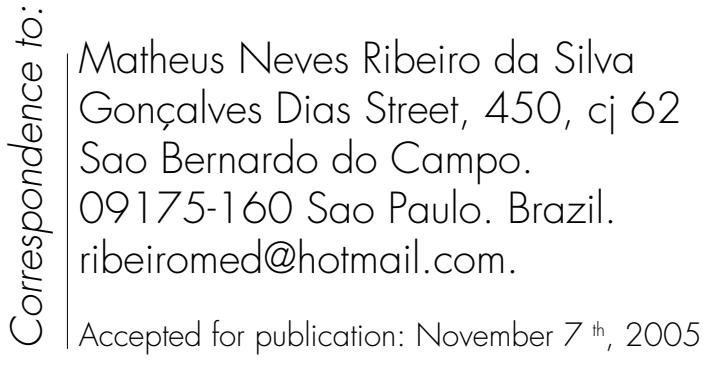

CONCLUSION: Although uncommon, vesical explosion during TURP may occur and some preventive measures, discussed herein, can be performed to avoid this complication.

Keywords: Transurethral resection. Vesical explosion.

Resumen.- OBJETIVO: La perforación vesical durante la resección transuretral de próstata (RTUP) está relacionada generalmente con grandes elevaciones de la presión intravesical. Sin embargo, en raras ocasiones puede estar relacionada con la explosión de los gases producidos durante la resección al entrar en contacto con el asa de electrocauterio. Presentamos un caso de explosión vesical, discutimos su mecanismo y sugerimos algunas medidas para prevenirlo.

MÉTODO/RESULTADO: Varón de 71 años de edad con hematuria persistente sometido RTUP y hemostasia de un punto sangrante en el cuello vesical. Se utilizó un asa de electrocauterio con la potencia de corte y coagulación de $80 \mathrm{~W}$. Durante la coagulación de un punto sangrante en la cara anterior del cuello vesical con la vejiga vacía se escucha un ruido y se nota una sacudida en el abdomen inferior. La inspección demuestra la existencia de un agujero en el fondo vesical por el que se observan asas de intestino delgado. Se realizó una incisión de laparotomía media infraumbilical y reparación de la ruptura vesical intraperitoneal.

CONCLUSIONES: Aunque es rara, la explosión vesical durante la RTUP puede ocurrir y se pueden tomar algunas medidas preventivas para evitarla.

Palabras clave: Resección transuretral. Explosión vesical. 


\section{INTRODUCTION}

Eletrocautery is widely used in endoscopic urological surgery and although regarded safe, explosions related to electricity have been anecdotally reported. Most cases are vesical explosions during transurethral resection of the prostate or bladder (1) However, an intrarenal explosion during ureteroscopic fulguration was documented in 1991 (2). We report a case of an intravesical explosion resulting in an intraperitoneal bladder rupture during transurethral resection of the prostate. We also reviewed the etiology of this complications and possible preventive measures.

\section{CASE REPORT}

A 71-year-old man presented to the emergency room with a 3-day history of continuous macroscopic hematúria. He underwent radiotherapy for localized prostate cancer 2 years previously. This neoplasm was biochemically controlled.

Transurethral resection of the prostate was then performed for prostate hyperplasia with bladder neck variceal bleeding. A 25Fr resectoscope sheath was used with a wire loop electrode set at a cutting and coagulating current of 80 watts. A $3 \%$ manitol solution was used as the irrigating fluid, on a continuous drainage system. On final inspection of hemostasy, a small bleeding was identified on the anterior aspect of bladder neck, near the air bubble. On initiation of the cautery a loud pop was heard and a jolt was felt at the lower abdomen. Inspection revealed a hole in the dome of the bladder with loops of small bowel visible.

A low midline incision was done, and the intraperitoneal bladder rupture was repaired. An approximately $4 \mathrm{~cm}$ hole near the dome of the bladder was closed in 2 layers,. A 22 Fr Foley catheter was left to drain the bladder. Postoperative course was complicated by bladder dehiscence, needing two consecutive bladder resuture.

\section{DISCUSSION}

The most common cause of bladder perforation during transurethral surgery is hiperdistension of the bladder wall when the amount of fluid infused is in excess, when the patient has a low vesical compliance or when excessive pressure is applied during evacuation of prostatic fragments. It occurs most commonly when a continuous drainage system is not used.
Bladder explosion as occurred in our patient is a rare complication of endoscopic surgery. The etiology of intravesical explosions is probably related to the formation of hydrogen gases during resection of human tissue. Ning et al performed in vitro experiments showing that hydrogen constituted approximately $50 \%$ of the gases produced by electrocautery (3). They theorized that the majority of hydrogen was derived from the electrolysis of intracellular water. Davis also performed in vitro experiments that confirmed at least $30 \%$ hydrogen formation in diathermy gases (4). He theorized that the majority of gases were produced during pyrolysis of tissues. Whereas hydrogen gas alone is not explosive, when mixed with atmospheric oxygen it may become combustible.

Although bladder explosion due to combustion is rarely report, we strongly believe that it was the cause of perforation in our patient because the bladder was empty and a explosion noise was heard. Moreover, the patient has possibly a most fragile bladder due to previous radiotherapy.

Several strategies are important to reduce the possibility of bladder explosion. Care should be taken to minimize the amount of air introduced in the bladder during irrigation. Air in the dome may be aspirated using a ureteral catheter or a suprapubic trocar. Suprapubic pressure may be used to reposition the location of the air bubble away from the area of interest, while placing the patient in the Trendelenburg may shift the air bubble. Decreasing the time of resection with judicious coagulating of tissues and using a moderate power setting for the coagulation current, are other suggested preventive measures (1).

\section{REFERENCES AND RECOMENDED READING}

\section{(*of special interest, ${ }^{* *}$ of outstanding interest)}

1. 1. HORGER, D.C.; BABANOURY, A.: "Intravesical explosion during transurethral resections of bladder tumors". J. Urol.; 172:1813; 2004

2. ANDREWS, P. E. and SEGURA, J. W.: "Renal pelvic explosion during conservative management of upper tract urothelial cancer". J. Urol., 146: 407, 1991

3. NING, T. C., Jr., ATKINS, D. M. and MURPHY, R. C.: "Bladder explosions during transurethral surgery". J. Urol., 114: 536, 1975

4. DAVIS, T. R.: "The composition and origin of the gas produced during urological endoscopic resections". Br. J. Urol., 55: 294, 1983 